Research Report No. 33/2007

\title{
Fundamental Enterprise Income Tax Reform in China: Motivations and Major Changes
}

Jinyan Li

Osgoode Hall Law School of York University, JLi@osgoode.yorku.ca

Follow this and additional works at: http:// digitalcommons.osgoode.yorku.ca/clpe

\section{Recommended Citation}

Li, Jinyan, "Fundamental Enterprise Income Tax Reform in China: Motivations and Major Changes" (2007). Comparative Research in Law \& Political Economy. Research Paper No. 33/2007.

http://digitalcommons.osgoode.yorku.ca/clpe/248 


\section{Comparative Research in Law \& Political Economy}

\section{J inyan Li}

Fundamental Enterprise Income Tax Reform in China: Motivations and Major Changes

EDTORS: Peer Zumbansen (Osgoode Hall Law School, Toronto, Director, Comparative Research in Law and Political Economy, York University), J ohn W. Cioffi (University of California at Riverside), Lindsay Krauss (Osgoode Hall Law School, Toronto, Production Editor) 

CLPE Research Paper 33/2007

Vol. 03 No. 06 (2007)

\title{
Jinyan Li
}

\section{FUNDAMENTAL ENTERPRISE INCOME TAX REFORM IN CHINA: Motivations AND MAJOR Changes}

\begin{abstract}
On 16 March 2007, the National People's Congress of China promulgated a new Enterprise Income Tax Law (EIT Law) to take effect on 1 January 2008. It is the first law in Chinese history that imposes an income tax on all forms of enterprise. It replaces the current FIE Income Tax Law applicable to enterprises with foreign direct investment and the Interim Enterprise Income Tax Regulations (Interim EIT Regulations) applicable to Chinese-owned enterprises. Most notably, the EIT Law abolishes the tax incentives applicable only to foreign-investment enterprises (FIEs) and introduces a general tax rate that is internationally competitive. The promulgation of the EIT Law symbolizes the maturity of China's tax policy, China's commitment to the principles of the World Trade Organization (WTO) and China's confidence in its economic development policy. This article provides some background on this fundamental tax reform and an overview of the key changes and their implications.
\end{abstract}

Keywords: Enterprise Income Tax Law, China, Enterprise, Tax Policy, World Trade Organization

JEL classification: K33, K34

Forthcoming in: Bulletin for International Fiscal Documentation (2007)

Author Contact: Jinyan Li

Osgoode Hall Law School, York University, Toronto ON

Email: jinyanli@osgoode.yorku.ca 


\title{
FUNDAMENTAL ENTERPRISE INCOME TAX REFORM IN CHINA: MOTIVATIONS AND MAJOR CHANGES
}

\author{
Jinyan $\mathrm{Li}^{*}$
}

\section{INTRODUCTION}

On 16 March 2007, the National People's Congress of China promulgated a new Enterprise Income Tax Law ${ }^{1}$ (EIT Law) to take effect on 1 January 2008. It is the first law in Chinese history that imposes an income tax on all forms of enterprise. It replaces the current FIE Income Tax $\mathrm{Law}^{2}$ applicable to enterprises with foreign direct investment and the Interim Enterprise Income Tax Regulations ${ }^{3}$ (Interim EIT Regulations) applicable to Chinese-owned enterprises. Most notably, the EIT Law abolishes the tax incentives applicable only to foreign-investment enterprises (FIEs) and introduces a general tax rate that is internationally competitive. The promulgation of the EIT Law symbolizes the maturity of China's tax

\footnotetext{
* Professor, Osgoode Hall Law School, York University, Canada; and Senior Fellow, Taxation Law and Policy Research Institute, Monash University, Australia. I thank He Huang for her excellent research assistance and David Piccolo for his comments on the draft of this article. Email: jinyanli@osgoode.yorku.ca

1 Enterprise Income Tax Law of the People's Republic of China, promulgated by the 5th Session of the Tenth National People's Congress, 16 March 2007 (hereafter "EIT Law"). The Chinese text of the law is available at the State Administration of Taxation web site: www.chinatax.gov.cn. An unofficial English translation is available at www.kpmg.com.cn and www.lehmanlaw.com.

2 Income Tax Law of the People's Republic of China on Foreign-Investment Enterprises and Foreign Enterprises, Chairman Order [1991], No. 45 (hereafter "FIE Income Tax Law"). The Chinese text is available at the State Administration of Taxation web site, supra note 1 .

3 Interim Regulations on Enterprise Income Tax, State Council Order [1993], No. 137 (hereafter "Interim EIT Regulations"). This was a consolidation of the Interim StateOwned Enterprise Income Tax (18 September 1984), State-Owned Enterprise Income Regulatory Tax (18 September 1984), Interim Collective Enterprise Income Tax (11 April 1985), and Interim Private Enterprise Income Tax (25 June 1988), all introduced by the State Council.
} 
policy, China's commitment to the principles of the World Trade Organization (WTO) and China's confidence in its economic development policy.

This article provides some background on this fundamental tax reform and an overview of the key changes and their implications. Part 2 briefly discusses the evolution of the current tax system, and Part 3 examines the motivations behind the promulgation of the EIT Law. The major changes in the tax rules and policies are discussed in Part 4. Part 5 concludes the article with some comments on the preliminary impact of the reform.

\section{The CURRENT TAX SySTEM}

\section{A. THE DUAL-TRACK SYSTEM}

The current enterprise income tax system came into existence in the early 1980s. ${ }^{4}$ At that time, China was trying to "get across the river [from a command economy to a market-based economy] by feeling the stones on the river bed" (mozhe shitou guohe). There was no bridge or precedence to guide China's economic transition. China had never had an income tax ${ }^{5}$ or a legal tradition familiar to foreign investors. ${ }^{6}$ The previous Maoist regime

4 See note 3, supra, for the introduction of some taxes. The Chinese-Foreign Equity Joint Venture Income Tax (EJVIT) Law was promulgated in 1980; the Income Tax Law of the People's Republic of China Concerning Foreign Enterprises was promulgated in 1981 (hereafter "FEIT" or "FEIT Law").

5 When the modern income tax was introduced in the United States (1913) and Canada (1917), China was undergoing civil wars and political turmoil, which ended when the Communist Party declared the establishment of the People's Republic on 1 October 1949. After 1949, foreign capital left China, and domestic private capital was confiscated. Capitalism and markets were incompatible with the Communist Party-led socialism. The absence of international investment and business transactions eliminated any need for international taxation. When foreign investors were allowed back into China in the late 1970s, it was considered appropriate to impose an income tax on them.

6 For more discussion on Chinese legal traditions, see Peerenboom, Randall, China's Long March toward Rule of Law (New York: Cambridge University Press, 2002); Lubman, Stanley B., Bird in a Cage -- Legal Reform in China after Mao (Stanford, Calif.: Stanford University Press (1999); Lubman, Stanley B., "Looking for Law in China", 20 Columbia Journal of Asian Law 1 (2006); Hsu, Stephen C. (ed.), 
left behind institutions that could not adequately support a legal system appropriate for a market-driven economy. The government under the leadership of Deng Xiaoping adopted a pragmatic, evolutionary approach to reform. ${ }^{7}$ Foreign direct investment (FDI) was to be encouraged, but kept separate from the domestic sector and subject to different regulatory regimes. In terms of taxation, the income of enterprises receiving FDI and FIEs (including equity joint ventures (EJVs), contractual joint ventures, wholly foreign-owned enterprises, and joint-stock companies with foreign shareholders) was taxed differently from the income derived by Chineseowned enterprises. ${ }^{8}$

\section{B. Preferential taX Regime FOR FDI}

The income taxes imposed by the FIE Income Tax Law (1991) and its predecessors (the EJVIT and FEIT Laws) ${ }^{9}$ are similar to the income taxes in Western countries. A main policy objective of these taxes is to attract FDI. This was accomplished by following the international tax norms, adopting low tax rates, and offering generous tax incentives. China's

Understanding China's legal system: essays in honor of Jerome A. Cohen (New York: New York University Press, 2003); and Ren, Xin, Tradition of the Law and Law of the Tradition (1997).

7 More importantly, the Communist Party was not interested in reforming the political system while embarking on economic reforms. How could market capitalism coexist with a Communist-led "people's democratic dictatorship"? There were, of course, no readily available answers to any of these questions. The Chinese leadership has resisted the advice of international experts to go for "big bang" economic reforms in favour of a more gradual, pragmatic approach. For more discussion, see Peerenboom, Randall, "What Have We Learned about Law and Development? Describing, Predicting, and Assessing Legal Reforms in China", 27 Michigan Journal of International Law 823 (2006); and Peerenboom, supra note 6, at 197.

8 For an overview of the evolution of China's tax system, see Brean, Don (ed.), Taxation in Modern China (New York and London: Routledge, 1998); Easson, Alex and Jinyan Li, Taxation of Foreign Investment in the People's Republic of China (The Hague: Kluwer, 1989); Fulton, T., Daniel Xu and Jinyan Li (eds.), China's Tax Reform Options (New York: World Scientific, 1998); Li, Jinyan, Taxation in the People's Republic of China (New York: Praeger, 1991); and Moser, Michael and Winston Zee, China Tax Guide (Oxford: Oxford University Press, 1987).

$9 \quad$ FIE Income Tax Law, supra note 2; EJVIT Law and FEIT Law, supra note 4. 
extensive treaty network covers these taxes and preserves China's tax incentives, mostly through a tax sparing credit in China's treaties with capital-exporting countries (with the notable exception of the United States).

International experience and tax norms were among the "stepping stones" used by Chinese officials in the early 1980s. The text of the basic tax legislation of selected developed countries (notably the United States, the United Kingdom and Japan) and developing countries (Brazil, Mexico and Singapore) as well as the OECD Model Tax Convention and the UN Model Convention was translated into Chinese. International tax experts provided crash courses on the fundamental international tax principles. Some Chinese officials were sent to study abroad. To the extent possible, the EJVIT Law adopted international tax concepts and principles, including the principle of worldwide taxation and the prevention of double taxation through a foreign tax credit.

The lack of a legal tradition familiar to Western investors and the absence of administrative experience with a modern tax law meant that the new income tax law had to provide sufficient "certainty" and legal assurances to foreign investors while being administratively feasible. The form of the legislation is "fa" or "law". ${ }^{10}$ In China's legislative hierarchy, it is the highest form of legislation and must be passed by the legislature -- the National People's Congress. The appearance of "the rule of law" was used only in the tax legislation applicable to foreign investors. Meanwhile, the EJVIT Law was a model of legislative simplicity. The whole text consisted of fewer than 1,000 Chinese characters and 18 articles. $^{11}$ Consistent with Chinese legal tradition, great powers were given to the tax administration. For example, the eligibility to receive most tax incentives required the pre-approval of the tax authorities.

\footnotetext{
10 "Law" is a statute enacted by the National People's Congress. China deemed it important to subject foreign investors to tax "laws", not just "interim regulations" or "administrative rules", in order to convey a sense of "the rule of law" to foreign investors.

11 Arts. 1 to 7 set forth the rules for tax jurisdiction, determination of the tax base, the tax rate and tax incentives. Art. 16 provided the foreign tax credit as the method of relieving international double taxation. The remaining ten articles were devoted to administrative matters, such as filing returns, the tax authorities' powers of investigation, dispute resolution and tax penalties.
} 
It was also clear at the beginning that tax policy would be used to attract FDI. Initially, foreign businessmen advised China to offer tax incentives for FDI. ${ }^{12}$ Chinese officials were aware of the tax incentives being offered by Indonesia, South Korea, Malaysia, Thailand, Singapore and other countries. ${ }^{13}$ They were advised that some international experts questioned the efficiency and effectiveness of tax incentives, ${ }^{14}$ but remained concerned that China would be unable to compete for FDI unless it offered tax incentives similar to those provided elsewhere. ${ }^{15}$ The EJVIT Law therefore granted tax incentives in the form of tax holidays and a reinvestment tax refund. ${ }^{16}$ Similar incentives were available under the FEIT Law. However, because China was not very enthusiastic about foreign companies operating in China without a local equity partner (typically a state-owned enterprise), the incentives under the FEIT Law were less generous. $^{17}$

During the 1980s and 1990s, there was a huge boom in establishing

12 See Pomp, Richard and Stanley Surrey, "The Tax Structure of the People's Republic of China", 20 Virginia Journal of International Law 1 (1979), at 12.

13 See Liu, Longheng, Introduction to Chinese Tax Law (Beijing University Press, 1986), at 240 (in Chinese).

$14 \quad$ Pomp and Surrey, supra note 12, at 12.

15 Id.

16 The standard tax holiday was three years (a one-year exemption and two years of a half reduction), starting in the first profit-making year. An extended holiday of ten years was available to EJVs engaged in low-profit operations in farming and forestry or located in remote, economically underdeveloped areas. Forty per cent of the income tax paid on the amount of profit reinvested in China would be refunded. Obtaining any of the tax preferences depended on the prior approval of the Ministry of Finance. The EJVIT Law formally incorporated the tax incentives previously promised in the EJV Law. The EJV Law provided that the income tax (which was not yet in existence) payable by Chinese-foreign EJVs was to be reduced or waived if the foreign investors brought "upto-date" technology to the joint venture or if the profit made in China was reinvested in China.

17 For example, a three-year tax holiday was available only if the investment was scheduled to operate for at least ten years in farming, forestry, animal husbandry or other low-profit operations. Upon approval by the Ministry of Finance, an additional tax reduction of $15 \%$ to $30 \%$ was available. Chinese-source investment income, including interest, rents and royalties, was subject to a $20 \%$ withholding tax. 
special preferential tax regimes for FDI. A major aspect of China's FDI policy was development region by region. The strategy was to concentrate limited resources for improving the infrastructure in small geographic areas. Another aspect of the policy was to encourage export, which could not only earn foreign currency, but also keep FDI separate from the domestic market.

Four "special economic zones" (SEZs) were created in 1980 along the south coast: Shenzhen, Zhuhai and Shantou in Guangdong Province (and close to Hong Kong) and Xiamen in Fujian Province (across from Taiwan). ${ }^{18}$ They were created to attract investors in general and investors from Hong Kong, Macau and Taiwan in particular. The State Council introduced temporary rules to grant special tax reductions and exemptions in the SEZs. ${ }^{19}$ These tax preferences applied to all forms of FDI and were more generous than those under the existing EJVIT and FEIT Laws. For example, the general tax rate was 15\% (as opposed to 30\%); the local tax was waived; the tax holiday was longer (five years instead of three) for "productive" enterprises (those engaged in manufacturing, communications and transport, agriculture, forestry, or animal husbandry); the refund for reinvestment was $100 \%$ (as opposed to $40 \%$ ); and the $10 \%$ withholding tax on dividends (or profit distributions) was waived. Most significantly, the SEZs set precedents for the authorities to establish preferences which help channel foreign capital and technology to other designated priority areas.

Fourteen "coastal economic open cities" were designated in 1984, and certain areas in them were designated as "economic and technological development areas" and others as "old urban districts". ${ }^{20}$ The tax

18 For more discussion on the SEZs, see Crane, George, The Political Economy of China's Special Economic Zones (1990); and Bucknall, Kevin B., China and the Open Door Policy (1989), at 143-167.

19 See Provisional Regulations of the State Council of the People's Republic of China Regarding the Reduction of and Exemption from Enterprise Income Tax and Consolidated Industrial and Commercial Tax in the Special Economic Zones and the Fourteen Coastal Cities, promulgated by the State Council on 15 November 1984.

20 The 14 coastal cities were Tianjin, Shanghai, Dalian, Qinhuangdao, Yantai, Qingdao, Lianyungang, Nantong, Ningbo, Wenzhou, Fuzhou, Guangzhou, Zhanjiang and Beihai. The list of "coastal economic open regions" was later expanded to cover over 170 cities and counties in eight provinces. 
incentives in the economic and technological development areas were very close to those in the SEZs, but the incentives in the coastal economic open cities were less generous. ${ }^{21}$ Many "coastal economic open regions", consisting of urban and rural areas in the Yangtze and Pearl River Deltas, and the South Fujian region, were designated in $1985 .^{22}$

In addition to special regions, special FDI projects or activities received preferential tax treatment. The two most well-known types of projects were export-oriented $^{23}$ and technologically advanced. ${ }^{24}$ On top of any tax exemption and reduction to which a taxpayer was entitled, the tax rate was reduced to $15 \%$ in general and $10 \%$ in the SEZs. ${ }^{25}$ For technologically advanced enterprises, the tax rate was reduced by half for three years following the standard tax holiday. Reinvestment in either type of enterprise was eligible for a full refund of the tax paid on the reinvested profit. Other preferred investments included infrastructure projects, ${ }^{26}$ "productive" activities, agriculture and animal husbandry. Services and passive investments were not encouraged.

21 See Jiang, Zhaodong, "China's Tax Preferences to Foreign Investment: Policy, Culture and Modern Concepts", 18 Northwestern Journal of International Law \& Business 549 (1998), at 611. For example, a reduced 15\% tax rate applied to EJVs, contractual joint ventures and wholly foreign-owned enterprises in the old urban districts which were technology or know-how intensive and had an investment exceeding USD 30 million and a long investment recovery period or if the projects related to energy, transport or port construction.

22 See Jiang, id.

23 "Export-oriented enterprises" were enterprises that produced goods mainly (over $70 \%$ ) for export and maintained a net positive foreign exchange balance at the end of the year.

24 "Technologically advanced enterprises" were enterprises which, with advanced technology provided by foreign investors, were able to develop new products or upgrade existing ones and therefore earn foreign exchange through exports or import substitution.

25 The tax rate was reduced to $10 \%$ for FIEs in the economic and technology development areas or other areas where the enterprise income tax rate was already $15 \%$.

26 Irrespective of the location of the investment, the tax rate was reduced to $15 \%$ for EJVs in port and berth construction projects. New projects scheduled to operate for 15 years or more were eligible for a ten-year tax holiday (a five-year exemption followed by a five-year $50 \%$ reduction in tax). The tax holiday might be extended upon approval by the Ministry of Finance. The withholding tax on profit distributions was waived as was the local income tax. See Jiang, supra note 21. 
The formal tax discrimination between EJVs and other forms of FDI seemed to make little sense by the end of the 1980s. By then, the majority of FDI was either located in special areas or involved in preferred investment projects, thus receiving similar tax preferences whether or not the form was an EJV. In 1991, the EJVIT and FEIT Laws were consolidated into the FIE Income Tax Law, ${ }^{27}$ but the existing tax incentives were preserved. After 1991, new tax incentives continued to be granted. The Pudong New District was created in the city of Shanghai ${ }^{28}$ in order to develop Shanghai into a world-class financial centre. Other "special" regions included western regions, north-east regions, border cities, bonded zones, tourist and resort areas, and "high and new technology industrial development areas". ${ }^{29}$ The rise of special areas away from the coastal regions effectively made the special tax regimes in the coastal regions less special. The coastal regions therefore created new types of special zones to remain competitive, including bonded zones, free trade zones, high and new industrial development zones, Taiwan investment zones, the Singapore-Suzhou industrial park, and tourist and resort zones. ${ }^{30}$

\section{TAXATION OF DOMESTICALLY-FUNDED ENTERPRISES}

State-owned enterprises, collective enterprises and private enterprises are currently taxed under different regulations, which were originally introduced in 1984 and subsequently (in 1993) consolidated into the

$27 \quad$ See notes 2 and 4, supra. For an overview of the tax implications for foreign investors, see Curley, Stephen and Darren Fortunato, "Tax Considerations for Investors in China: A Preliminary Look", 20 North Carolina Journal of International Law and Commerce Regulation 531 (1995); Li, Jinyan, "Tax Implications of Doing Business in China", 43 Canadian Tax Journal 75 (1995); Li, Jinyan, "Taxation of Foreign Business and Investment in the People's Republic of China", 7 International Business and Tax Lawyer 120 (1989); and Lin, Kenny, "Income Taxation and Foreign Direct Investment in China", 25 International Tax Journal 78 (1999).

Id.

30 Id. 
Interim EIT Regulations. ${ }^{31}$ Although the Interim EIT Regulations and the FIE Income Tax Law have the same statutory rate of 33\%, the effective tax rate for FIEs is about 10 percentage points lower because of the tax incentives discussed above and the limitations on deductions in the Interim EIT Regulations. For example, while the FIE Income Tax Law allows a full deduction for the interest expenses incurred for income-producing purposes, the Interim EIT Regulations limit the deduction to the interest charged at the rate set by government-owned financial institutions. As such, many enterprises cannot deduct the full interest expenses because they had to borrow from non-state-owned banks that charged a higher interest rate. Similarly, wages and salaries are not deductible under the Interim EIT Regulations if the amount exceeds the standard amount specified by the government. With the liberalization of the labour market, the government-specified wage standard is much lower than the wages paid by enterprises, especially non-state-owned enterprises. This means that the excessive cost is not tax deductible.

So long as the foreign-funded firms did not compete with Chinese firms, the most effective way of using the tax system to attract FDI was to give tax incentives only to foreign investors. ${ }^{32}$ By the turn of the century, especially after China's accession to the WTO in 2001, the FDI tax policy was under close scrutiny and heatedly debated. When local firms began to suffer from the preferential treatment given to foreigners, China switched to a universally low corporate tax rate of $25 \%$.

\section{MOTIVATIONS FOR TAX REFORM}

In explaining the draft law to the National People's Congress, the Minister of Finance identified the following as the guiding principles for the new law: ${ }^{33}$

\footnotetext{
$31 \quad$ See note 3 , supra.

32 As discussed below, such differential policy resulted in round-tripping. However, round-tripping was presumably not considered a serious problem because China did not make it very difficult for those engaged in round-tripping. The alternative would have been to grant tax incentives to all taxpayers, which would be costly in terms of revenue.
}

33 Jin, Renqing, Minister of Finance, "Explanation on Draft Enterprise Income Tax 
-equal taxation of all enterprises;

-the promotion of overall, sustainable development of China's economy;

-reference to the international tax norms and practices; and

-efficiency in tax administration and simplicity in compliance.

\section{A. EQUAL/NEUTRAL TAXATION}

The hallmark of the new EIT Law is equal taxation of all enterprises, irrespective of the source of capital. Foreign-funded and domesticallyfunded enterprises are taxable under the same rules. The tax preferences that were available only to FIEs are now abolished or are to be phased out in five years. As discussed in more detail below, this shift in tax policy indicates China's confidence in attracting FDI without tax incentives.

China initially introduced the FDI tax incentives in part to compensate investors for the lack of market or investment conditions. During the early years of the reform, these incentives played a positive role in attracting investment, which in turn promoted the development of a market mechanism in China and propelled economic growth. However, the differential tax policy was difficult to maintain when FIEs were allowed greater access to the Chinese internal market, especially after China's accession to the WTO in 2001. Foreign firms have gradually been allowed to own up to $50 \%$ of enterprises in sensitive industries, such as telecoms, banking and insurance. Multinational companies have taken over Chinese companies in a quest for economies of scale. The FDI tax incentives have aided such foreign takeovers. In 2006, foreign investors controlled the majority of assets in 21 out of 28 major industrial sectors. ${ }^{34}$ Given the large amount of FDI in China, domestically-funded companies are facing tax discrimination in addition to the challenges resulting from the control and market power of multinational firms on the Chinese market. The potential dominance of key economic sectors by multinational firms,

Law". The full text of the speech in English is available at www.chinaembassy.org/eng/gyzg/t302221.htm (visited on 31 July 2007).

34 Shi, Weigan, "A Reexamination of the Role of Foreign Investors", 1 September 2006, available at finance.sina.com.cn (in Chinese). 
assisted by the tax system, became a serious concern. ${ }^{35}$ Chinese-owned enterprises cried for "national treatment" from their own government. The Minister of Finance, Jin Renqing, acknowledged this in his explanation of the draft law to the National People's Congress: ${ }^{36}$

Great changes have taken place in China's economy and society, and the socialist market economy has initially taken shape. With China's accession to the WTO, the Chinese domestic market has been further open to foreign capital; domestic enterprises have gradually integrated themselves into the world economy and are facing everincreasing competition. If different tax policies continued to be implemented for domestic and foreign-funded enterprises, the former would definitely be put at a competitive disadvantage and the establishment of a unified market with standardized and fair competition would be obstructed.

\section{B. Promoting SUSTAINABLE ECONOMIC DEVELOPMENT}

The EIT Law represents a fundamental change in China's tax policy -from the preferential taxation of FDI to the neutral taxation of all enterprises. It also reflects a fundamental shift in China's economic development strategy -- from a focus on FDI-led manufacturing and export to a focus on technology and sustainable economic development. ${ }^{37}$ The FDI preferential tax policy was geared to promote the former model of development and regional development, and its effectiveness and efficiency has become questionable in recent years.

35 See Fung, Hung-Gay, Julius Johnson, Jr. and Yanda Xu, "Winners and Losers: Foreign Firms in China's Emerging Market", 37 The Chinese Economy 5 (No. 3, 2004).

$36 \quad$ Jin, supra note 33.

37 For an overview of this policy shift, see Whalley, John and Weimin Zhou, "Technology Upgrading and China's Growth Strategy to 2020", Centre for International Governance and Innovation (CIGI) (March 2007), available at papers.ssrn.com/sol3/papers.cfm?abstract_id=982232. 
There is no denial that FDI has been considered to be the "engine" of China's rapid economic growth: FIEs contributed about $0.4 \%$ to China's annual GDP growth during the 1990 s, ${ }^{38}$ helped China build a highly competitive and dynamic manufacturing sector for exports, ${ }^{39}$ and affected China's economic growth through the diffusion of ideas and transfer of technology. ${ }^{40}$ However, the extent to which FDI was attracted to China because of its tax incentives or whether the incentives were economically efficient is unclear.

Scholars who argue that the tax incentives were effective in attracting FDI to China ${ }^{41}$ often refer to the general data on the FDI growth in China ${ }^{42}$ and the fact that over $80 \%$ was located in the tax-preferred coastal areas. ${ }^{43}$

\footnotetext{
38 Tseng, Wanda and Harm Zebregs, "Foreign Direct Investment in China: Some Lessons for Other Countries", IMF Policy Discussion Paper PDP/02/03.

39 Zhang Tao, "Utilization of Foreign Capital and Economic Growth in China", 37 The Chinese Economy 62 (No. 1, 2004).

40 See Dees, Stephane, "Foreign Direct Investment in China: Determinants and Effects", 31 Economics of Planning 175 (1998)

41 See e.g. Li, Gang and Guangyi Chen, "Direction of Chinese International Tax Law under WTO Principles", in Liu, Jianwen (ed.), 8 Finance and Tax Law Review 281 (2006), at 298 (Beijing: Law Press China, 2006) (in Chinese); Cheng, Leonard K. and Yum K. Kwan, "What are the Determinants of the Location of Foreign Direct Investment? The Chinese Experience", 20 Journal of International Economics 375 (2000); and Tung, Samuel and Stella Cho, "The Impact of Tax Incentives on Foreign Direct Investment in China", 9 Journal of International Accounting, Auditing \& Taxation 105 (No. 2, 2000).
}

42 The annual value of FDI actually utilized in China is as follows: USD 4.1 billion in 1979-1984, USD 1.9 billion in 1985, USD 34.8 billion in 1990, USD 37.5 billion in 1995, USD 40.7 billion in 2000, and USD 60.3 billion in 2005. Source: China Statistical Yearbook (2006), available at www.stats.gov.cn/tjsj/ndsj/2006/html/R1814E.xls (visited on 10 July 2007).

43 Jiang, Xiaojuan, Yingxin Wang and Laike Yang, "A Study of the Gradual Shift of Foreign Investment", 37 The Chinese Economy 19 (No. 5, 2004); Chen, Chun, "Reflections on the Matter of Foreign Tax Preferences", [2005] International Taxation in China, No. 7 at 31 (in Chinese). On the other hand, there are obvious non-tax factors that are attractive to FDI: the special areas on the east coast generally have a longer history of openess to investors; better infrastructure; a more open, transparent and efficient local government; a better educated workforce; and higher purchasing power. Hon, Tai-Yuen, Che-Cheong Poon and Kai-Yin Woo, "Regional Distribution of Foreign Direct Investment in China: A Multivariate Data Analysis of Major Socioeconomic Variables", 
Using the FDI growth as a basis for asserting the effectiveness of tax incentives is unreliable as it fails to identify the amount of FDI inflow that would not have occurred in the absence of the tax incentives. More weight may have been given to the tax incentives as an influencing factor. The apparent correlation between the location of FDI in China's coastal areas and the location-specific tax incentives is misleading as evidence of the effectiveness of tax incentives because the general investment environment in the coastal areas has been more conducive to investment than the rest of China. Since most exports are competitive in labour costs and there is little regulation regarding pollution, labour protection, health, and safety controls, it is possible that labour-intensive, export-oriented investment would have taken place anyway.

Historically, tax incentives have played a positive role in attracting FDI. Granting tax incentives sent a clear signal of China's desire for investment by foreigners. This signalling effect was historically important because China suffered from serious image problems due to its previous hostile policies towards foreign investors. The choice of the very word in the Chinese language, "you hui" (preferences) for tax incentives conveyed a positive message. ${ }^{44}$ Tax preferences were presented by China as gifts or rewards to overseas investors.

Tax incentives appear to have been effective in attracting overseas Chinese investors and investors looking for a low-cost manufacturing base. Once the tax incentive regime was firmly in place, it became a constant factor and had much less influence. For example, following China's accession to the WTO, the fate of the FDI tax incentives was publicly debated in China, ${ }^{45}$ but in spite of their uncertainty and possible

38 The Chinese Economy 56 (No. 2, 2005) (a fundamental determinant of regional disparity in FDI in China in 1998-2003 was the overall socioeconomic environment in the administrative regions).

$44 \quad$ Jiang, supra note 21 , at 611.

45 See Guo, Hong, "Principles and Directions of China's Foreign Tax Incentives", [2005] Taxation Research Journal, No. 11 at 14 (in Chinese); Ma, Guoqiang, "Current Chinese Tax Incentives: Problems and Suggestions", [2003] Taxation Research Journal, No. 3 at 34 (in Chinese); and Liang, Jiang, "Problems with China's Current Tax Incentives for Science and Technology", [2001] Taxation Research Journal, No. 10 at 35 (in Chinese). 
elimination, FDI continued to increase in China. Investors who are lured to China by its domestic market, such as retail, telecoms, banking, services and certain consumer products, are less affected by tax incentives. Large multinational enterprises are found to be less influenced by China's tax incentives than small and medium-size firms. ${ }^{46}$ Presumably, multinationals are more interested in the long-term investment environment than the short-term effect of tax incentives. They can use tax planning techniques to achieve an effective tax rate target that is much lower than the formal tax rate.

Meanwhile, generous tax incentives have caused "round-tripping" in China. ${ }^{47}$ Chinese investors, who would otherwise pay tax at least 10 percentage points higher than FIEs, have been motivated to set up entities in tax havens to channel their investment in China. The People's Daily ${ }^{48}$ reported:

The British Virgin Islands is a major destination for China's offshore investment. ... 10,000 out of 500,000 companies there are from China. Most China-originated money entering tax havens will re-enter China as "foreign investment" - "round-tripping". ... A closer examination of China's star foreign direct investment (FDI)

46 Shan, Wenhua, "Law and Foreign Investment in China: General Role of Law
and Substantive Issues (part one)", 2 Manchester Journal of International Economic Law
41 (2005); Zhang, Yang and Hui Liu, "Analysis of the Impact of Taxation on FDI",
2006] Taxation Research Journal, No. 4 at 39, 41 (in Chinese). Shan also reached this
conclusion in his empirical study; he noted that tax incentives were regarded as an
important factor in the location of FDI on the basis of the investors surveyed. However,
the "widely held assumption that Western investors do not care much about incentives"
remains valid as it reflects the opinions and experiences of large multinationals which
account for the vast majority of international investors in terms of the amount of their
investment, but a tiny minority in terms of their number.

47 In Easson, Alex J., "Tax Incentives for Foreign Direct Investment -- Part II: Recent Trends and Countertrends", 55 Bulletin for International Fiscal Documentation 12 (2001), at 367, the author argued that round-tripping may happen whenever tax incentives are given only to foreign investors.

48 China Daily, "Investment outflows to tax havens", People's Daily Online, 22 June 2004, available at english.peopledaily.com.cn/200406/22/eng20040622_147138.html (visited on 31 July 2007). 
figures reveals a large amount of capital going out of the country and returning under a different guise. The World Bank and other experts have estimated the scale of this round-tripping could be as large as $20 \%$ to $30 \%$ of the total FDI inflow into China, but there is no clear definition and detailed estimation method behind the numbers. ... Even worse is that the trend is growing bigger. ... The biggest pay-off for recycling mainland-originated money through a web of companies offshore is the tax concessions that China grants to foreign firms.

Round-tripping is clearly not the type of investment to be encouraged by the tax incentives. Furthermore, the form of tax incentives (tax holidays) tends to encourage short-term investment projects. To the extent that tax incentives affected investment decisions, they encouraged investors to terminate a project as soon as the tax holiday was over and start a new project to qualify for a new tax holiday.

In lieu of FDI-specific tax incentives, China hopes to better attract FDI by offering lower tax rates than other countries. The $25 \%$ general tax rate was chosen because it was internationally competitive. The Minister of Finance stated: ${ }^{49}$

[T] he level of enterprise income tax rates in the world, especially the neighboring countries (regions), has to be taken into account. The average enterprise income tax rate is 28.6 percent in 159 countries (regions) around the world in which an enterprise income tax is applied, while that in China's 18 neighboring countries (regions) is 26.7 percent. The rate of 25 percent set in the Draft is relatively low in the world and will be conducive to enhancing enterprise competitiveness and attracting foreign investment.

\section{INTERNATIONAL TAX NORMS AND PRACTICES}

As mentioned earlier, the enterprise income tax system came into existence with the promulgation of the EJVIT (1980) and FEIT (1981)

\footnotetext{
$49 \quad$ Jin, supra note 33.
} 
Laws, both of which incorporated elements of the international tax norms. In the interest of attracting FDI through tax policy and recognizing the increasing globalization of China's economy, the drafters of the EIT Law intended to move China's enterprise income tax system closer to the international norms.

The basic structure of the EIT Law is based on the FIE Income Tax Law, which incorporated many concepts and principles of corporate taxation used in other countries. Adopting a uniform rate for all enterprises and using tax incentives to encourage small business, research and development, and other activities are consistent with the international tax norms. For the first time, Chinese tax law has adopted a controlled foreign corporations (CFC) rule, thin capitalization rules, and a statutory general anti-avoidance rule.

\section{ADMINISTRATIVE EFFICIENCY AND SIMPLICITY IN COMPLIANCE}

The dual-track system was very complex to administer. Two separate administrative regimes were required. Because the FIE Income Tax Law was "international" and the Interim EIT Regulations were "domestic", tax administrators virtually used different languages. The Chinese and foreign partners of a joint venture had to work with two separate laws: the Interim EIT Regulations for the Chinese partner and the FIE Income Tax Law for the foreign partner. When a Chinese company was acquired by a foreign investor, its tax status was transformed, and so was the system of tax compliance.

Furthermore, the FDI-specific tax incentives were known to be misused and abused by taxpayers. ${ }^{50}$ The above-mentioned round-tripping is just one example. The tax incentive legislation gave a great deal of discretion

\footnotetext{
50 See Li, Tingxu, "Means of Tax Avoidance and Tax Evasion by Foreign Investment Enterprises and Prevention Measures", [1999] International Tax Journal of China, No. 8 at 62 (in Chinese); Tie, Wei, "Causes and Assessment of Tax Avoidance under Current Tax System", [2005] International Taxation in China, No. 11 at 32 (in Chinese); and Ye, Jun, "To Repeal or Not to Repeal the Foreign Tax Incentive Policies", [2005] International Tax Journal of China, No. 11 at 28 (in Chinese).
} 
to the tax authorities to approve the tax incentives. ${ }^{51}$ The lack of transparency and accountability in administering the tax incentive legislation tended to lead to graft, corruption and rent-seeking. ${ }^{52}$ Local governments engaged in fierce tax competition by lobbying the central government for more tax preferences and offering tax incentives. ${ }^{53}$

The principle of making a tax payment easier and reducing the cost for both taxpayers and tax administrators has always been important in China. The lack of any history with a modern income tax system in China meant that the fate of the modern tax system was largely determined by the effectiveness of the administration and its efficiency. As such, this principle was paramount in China. About half of the articles in the EJVIT Law were devoted to administrative matters. In the new EIT Law, eight out of 60 articles are administrative provisions. In addition, more rules are prescribed in the Tax Collection and Administration Law. As compared with its predecessors, the EIT Law is more transparent in terms of taxpayers' obligations and the tax authorities' powers.

\section{MAJOR PRovisions of THE NEW LAW}

\section{A. OVERVIEW}

The EIT Law is a landmark piece of legislation in Chinese tax history. It

51 For example, Art. 8 of the FIE Income Tax Law states: "Any enterprise with foreign investment which is engaged in agriculture, forestry or animal husbandry and any other enterprise with foreign investment which is established in remote underdeveloped areas may, upon approval by the competent department for tax affairs under the State Council of an application filed by the enterprise, be allowed a $15 \%$ to $30 \%$ reduction of the amount of income tax payable for a period of 10 years ...."

52 See Wei, S., Does Corruption Relieve Foreign Investors of the Burden of Taxes and Capital Controls?, World Bank, Policy Research Working Paper 2209 (1999); and Drabek, Zdenek and Warren Payne, The Impact of Transparency on Foreign Direct Investment, World Trade Organization, Staff Working Paper ERAD-99-02 (2001).

53 See Li and Chen, supra note 41; and Liang, Jiang, "China's Current Tax Preferences of High-Tech and the Problems", [2001] Taxation Research Journal, No. 10 at 35 (in Chinese). 
not only unifies the FIE Income Tax Law and the Interim EIT Regulations, but also introduces new concepts and provisions. The Minister of Finance highlighted "four unifications": unification of the income tax law applicable to both domestic and foreign-funded enterprises, unification of the tax rates, unification and standardization of the deductions in computing taxable income, and unification of the tax incentives. ${ }^{54}$ Most of the new provisions deal with international tax avoidance transactions, such as thin capitalization, transfer pricing, and foreign corporations located in low-tax jurisdictions.

Consistent with China's legislative practice, most details for implementing the EIT Law will be spelled out in the implementation regulations to be promulgated by the State Council. At the time of writing (30 September 2007), these regulations have not been released. Because the EIT Law will take effect on 1 January 2008, the lack of such detailed rules leaves many taxpayers and their tax advisers in a state of uncertainty. The discussion below is based on the text of the EIT Law.

\section{B. LIABILITY TO TAX}

Enterprises are subject to tax under the EIT Law. Resident enterprises are subject to tax on their income from inside and outside China; non-resident enterprises are subject to tax only on their Chinese-source income.

The concept of "enterprise" is not defined. It is "one of the most perplexing aspects of Chinese enterprise law". ${ }^{55}$ An entity that is created under the authority of a statute is clearly an "enterprise" whose existence is distinct from the natural or legal persons who participate in its operations. In some cases, government institutions give real and meaningful effect to the existence of entities with no apparent statutory basis or whose legal basis dictates consequences that seem at odds with

\footnotetext{
$54 \quad$ Jin, supra note 33.

55 Clarke, Donald C., "How Do We Know When an Enterprise Exists? Unanswerable Questions and Legal Polycentricity in China", 19 Columbia Journal of Asian Law 50 (2005).
} 
the consequences called for by a constitutionally superior law. ${ }^{56}$ The uncertainty is more prevalent for domestically-funded entities because the legal regime for FDI is more standard and transparent. Taxpayers under the FIE Income Tax Law are "enterprises" under the EIT Law.

The term "resident" is defined as any legal person that is created under Chinese law or has its effective management in China. A "legal person" can be a Chinese-owned corporation ${ }^{57}$ or enterprise or an FIE. A legal entity created under Chinese law is a resident by virtue of the place of creation. A corporation created under foreign law is generally a nonresident of China, unless its place of effective management is in China. China's tax treaties define "resident" in a manner similar to the definition in Art. 4 of the OECD Model. A resident is a person liable to tax under the laws of a contracting state by reason of domicile, residence, place of head office, place of management, or any other criterion of a similar nature. If a legal person has dual residence, the place of effective management is typically the tie-breaker.

Non-resident enterprises are not taxable in China unless they derive Chinese-source income. Foreign corporations carrying on business operations in the form of a branch or through a partnership are subject to Chinese tax on the profit derived from the activities in China. ${ }^{58}$ Business income is taxable in China if the business is carried on through an establishment or site in China. An "establishment" typically refers to a management office, business site, office, factory, place of extraction of natural resources, site for contracted projects (such as construction, installation, assembly or exploration projects), site for furnishing services, and a business agent (EIT Law, Art. 3). The concept is tied to the physical presence of a foreign enterprise or its business agent in China. China's tax

\footnotetext{
$56 \quad$ Id.

57 Company Law of the People's Republic of China, Act of 19 December 1993.

58 Foreign corporations are allowed to carry on business activities in China in the form of a branch (Company Law, id., Art. 119). They can also establish a representative office but only if a Chinese enterprise sponsors it, and the activities of a representative office are limited to indirect business operations, marketing, promotion, equipment service and business communications. See Art. 4 of the Interim Regulations of the State Council of the People's Republic of China Concerning the Control of Resident Representative Offices of Foreign Enterprises, Act of 30 October 1980.
} 
treaties generally permit China to tax the business profits of an enterprise in a treaty partner's country only if the profits are derived from a business carried on through a permanent establishment in China.

Portfolio investment in China remains limited. ${ }^{59}$ In 2005, while the FDI inflow was valued at over USD 603 billion, Chinese companies issued USD 1.6 billion worth of shares overseas and entered into international leasing transactions worth USD 1.08 billion. ${ }^{60}$ Technology transfers are generally associated with FDI; FIEs imported more than half of the foreign technology imported into China. ${ }^{61}$ Non-residents deriving dividends, interest, rents and royalties from Chinese sources are subject to a $20 \%$ withholding tax. China's tax treaties often reduce the rate to $10 \%$ or lower. Capital gains derived by non-residents are taxable in China if the gains are realized from the sale of buildings, structures and affiliated facilities, landuse rights in China, or other property situated in China.

\section{TAXABLE INCOME}

The determination of taxable income is generally the same as under the FIE Income Tax Law. The details for the determination will be prescribed in the forthcoming implementation regulations. In principle, a taxpayer's taxable income is the amount of gross income ${ }^{62}$ reduced by deducting excluded income, ${ }^{63}$ exempt income, costs and expenses, and loss carry-

59 Deriving portfolio income in China through a Chinese resident corporation is not yet common. Chinese regulations generally require FIEs to be engaged in business activities. Investment holding companies are allowed to hold investments only in the same corporate group.

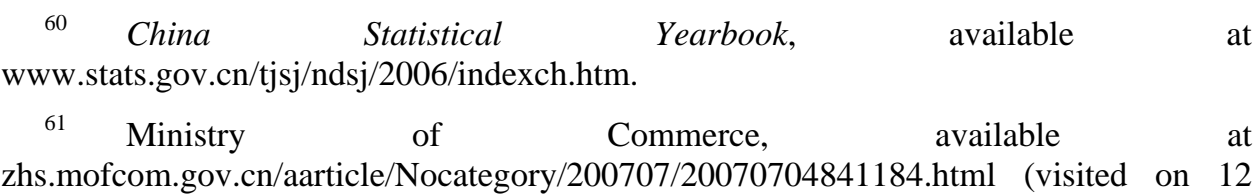
July 2007).

62 "Gross income" is defined as "an enterprise's monetary and non-monetary income from various sources" (EIT Law, Art. 6).

63 "Excluded income" is defined as income from fiscal funds such as fiscal appropriations, administrative charges subject to fiscal administration, and government funds (EIT Law, Art. 7). 
forwards (EIT Law, Art. 5).

Under the existing law, domestic enterprises and foreign-funded enterprises are subject to different rules for deducting costs and expenses. For example, domestic enterprises may deduct a limited amount of the salaries and wages paid, while FIEs may deduct the actual amount paid. The EIT Law unifies the deduction rules, allowing enterprises to deduct the costs and expenses actually incurred. The EIT Law prescribes the standards for deducting expenses only in the case of public welfare donations (EIT Law, Art. 9) and defines the scope of non-deductible expenses (EIT Law, Art. 10). Surprisingly, the loss carry-over is still limited to a five-year carry-forward; no carry-back is allowed.

\section{TAX RATES}

Art. 4 of the EIT Law unifies the rates. ${ }^{64}$ The general rate is $25 \%$, which is much lower than the effective rate currently applicable to domestic enterprises, but higher than that for FIEs. ${ }^{65}$ The $25 \%$ was considered to be internationally competitive, ${ }^{66}$ although it is twice as high as that in Ireland and Hong Kong.

A lower rate of $20 \%$ applies to small and low-profit enterprises. The lowest rate of $15 \%$ applies to new and high-tech enterprises that are supported by the state as key enterprises. The Minister of Finance explained that the lower rates for high-tech enterprises and small and lowprofit enterprises are justified because they play a special role in the national economy and, according to international practice, these types of

64 Under the existing law, the standard statutory tax rate is $33 \%$. The rate is lowered to $24 \%$ or $15 \%$ for FIEs in some special regions and to $27 \%$ or $18 \%$ for lowprofit domestic enterprises. There is a large disparity between the statutory tax rate and effective tax rate as a result of various tax incentives.

65 The estimated amount of the tax reduction for domestic enterprises was CNY 134 billion and the tax increase for FIEs was CNY 41 billion, resulting in an overall revenue loss of CNY 93 billion. The revenue decrease was considered acceptable to the government; see Jin, supra note 33.

66 Jin, id. See the statement of Minister of Finance Jin regarding the tax rates (quoted in the text at note 49, supra). 
enterprises receive support from the government in other countries. ${ }^{67}$ It is expected that a significant number of FIEs will qualify for the lower rates.

Local governments may waive or reduce a portion of the tax that belongs to the local government under the central-local fiscal arrangement.

\section{E. TAX INCENTIVES}

The new EIT Law abolishes most of the tax incentives discussed earlier. Instead of targeting FDI, the new tax incentives encourage designated activities or types of income in order to promote overall, sustainable economic growth. Tax-preferred investments and activities include those in agriculture, forestry, animal husbandry, fisheries, public infrastructure, environmental protection, conservation of energy and water resources, research and development, and transfers of technology (EIT Law, Art. 27).

The forms of tax incentives are more flexible. In addition to the traditional tax rate reductions, the EIT Law provides the following forms:

(a) accelerated deductions for expenditures for research and development, for fixed assets, and to create jobs for the disabled (EIT Law, Art. 30);

(b) additional deductions for a proportion of the capital contributions to qualified venture capital enterprises (EIT Law, Art. 31);

(c) exemption of income from the comprehensive utilization of resources or manufacturing of products that are consistent with the state's industrial policies (EIT Law, Art. 34);

(d) exemption of interest on state bonds, dividends received from resident corporations, dividends received by non-resident enterprises from resident enterprises, and income of non-profit enterprises (EIT Law, Art. 26);

(e) investment credit for investment in equipment used for

$67 \quad$ Jin, supra note 33. 
environmental protection, conservation of energy or water, or production safety (EIT Law, Art. 31). Additional incentives may be granted to enterprises in key industries or projects that are supported and encouraged by the state (EIT Law, Art. 25); and

(f) special relief authorized by the State Council for emergencies that have a major impact on regular business activities (EIT Law, Art. 36).

It was feared that eliminating the existing tax incentives and increasing the general tax rate for FIEs could potentially discourage FDI in China. To ease this fear, Art. 57 of the EIT Law allows existing FIEs to continue to pay tax at the lower rate of $15 \%$ or $24 \%$ until 2013 or to enjoy other types of tax incentives (such as tax holidays) until the specified time period is over. For existing FIEs that have not started enjoying the tax holidays because they have not yet made a profit, the tax holiday will start in 2008 and end in 2013.

Overall, there is some continuity in China's tax incentive policy. High-tech businesses continue to receive tax incentives in the form of a lower tax rate $(15 \%)$ as well as accelerated deductions for research and development. The preferential tax policy continues to apply to investments in agriculture, forestry, animal husbandry, fisheries and infrastructure construction. State-encouraged projects (such as those in Pudong and the western regions) continue to qualify for tax incentives. The abolished tax incentives include the tax rate reductions for FIEs in special areas and the incentives for export-oriented FIEs.

4.6. Foreign tax credit

The foreign-source income derived by resident enterprises is taxable under the EIT Law, subject to a foreign tax credit for the foreign income tax paid on the foreign income (EIT Law, Art. 23). More specifically, the foreign tax credit system operates on a worldwide basis. There is no distinction between business income and passive income in determining the limit on the foreign tax credit. Any excess credit may be carried forward for five years, but not refunded.

For the first time, China allows an indirect foreign tax credit: a credit may be claimed for any foreign corporate income tax attributable to the dividends received by a Chinese corporate shareholder from a non-resident 
corporation that is controlled directly or indirectly by a Chinese resident (EIT Law, Art. 24).

\section{F. ANTI-AVOIDANCE RULES}

The EIT Law contains the typical anti-avoidance rules found in other countries. The Minister of Finance explained the need for such rules as follows: ${ }^{68}$

Tax avoidance by some enterprises through various means is serious, and the struggle against tax avoidance is intense. Thus, on the basis of international practice, the Draft provides rules for preventing tax avoidance through transfer pricing among associated enterprises. It also provides general anti-avoidance rules and articles against thin capitalization and avoidance through tax havens. Moreover, it sets forth provisions for assessment procedures and collection of interest from settling tax arrears as provided for by the State Council. This will help guard against and prevent tax avoidance and safeguard the interests of the state.

\section{TRANSFER PRICING}

The EIT Law provides the following rules to address transfer pricing, which is recognized as a serious problem in China: ${ }^{69}$

\footnotetext{
68 Id.

69 Even with generally lower tax rates and generous tax incentives, multinational corporations apparently use transfer pricing techniques to shift profits away from China. This may appear to be surprising. But a closer look at the top source jurisdictions for the FDI inflow to China reveals the motivation for some investors. Hong Kong does not tax income derived from outside Hong Kong. Hence, savings in Chinese tax directly benefit the investors. Barbados, the British Virgin Islands, the Caymen Islands, etc., are wellknown tax havens. Deflecting profits away from China to these jurisdictions reduces the foreign investor's worldwide tax burden. In the past, Chinese tax law had a built-in incentive for foreign investors to indefinitely prolong the loss period in that the tax holidays started to run continuously from the first year of making a profit. Approximately $60 \%$ to $70 \%$ of FIEs reported tax losses. For further discussion, see Sherwood, Stanley G. and Peter G. Chen, "China's Transfer Pricing Wall", [2002] Tax Planning International
} 
Article 41:

Where business transactions between an enterprise and its associated enterprises are not based on the arm's length principle, resulting in the reduction of the taxable income of the enterprise or its associated enterprise, the tax authority has the power to make adjustments based on any reasonable methods.

Costs associated with joint development, transfer of intangible assets, or joint provision or receipt of services by an enterprise and its associated enterprises should be allocated on the basis of the arm's length principle for the purpose of computing taxable income.

Article 42:

An enterprise may provide the tax authority with the pricing principles and computation methods in respect of its related party transactions. After negotiations and verifications with the enterprise, the tax authority may enter into an advance pricing arrangement with the enterprise.

Article 43:

When an enterprise files an annual enterprise income tax return with the tax authority, it must also enclose an annual report on its transactions with its associated enterprises.

When the tax authority conducts its investigation of related party transactions, the enterprise, its associated enterprise, and any other enterprise that is relevant to the investigation must provide the relevant materials in accordance with the regulations.

Article 44:

When an enterprise fails to provide materials relevant to the related party transactions, or provides false or incomplete information that

Transfer Pricing, No. 2 at 9, 10; Li, Jinyan, Chapter China, in The Tax Treatment of Transfer Pricing (Amsterdam: IBFD Publications, loose-leaf); and Wu, Xiupo, "Reasons for Transfer Pricing in China", [2001] International Taxation in China, No. 2 at 30 (in Chinese). 
cannot truly reflect the reality of related party transactions, the tax authority is authorized to assess the enterprise's taxable income in accordance with the law and regulations.

These provisions incorporate the existing transfer pricing rules, ${ }^{70}$ which generally follow the OECD Transfer Pricing Guidelines. For the first time, however, the EIT Law addresses cost-sharing arrangements (see Art. 41(2)) and advance pricing arrangements (APAs) in the tax law (as opposed to administrative guidelines). These developments are welcome to multinational enterprises that would like to use these arrangements in China. In the past, multinational companies were less willing to share intellectual property or services with their Chinese subsidiaries for various reasons, a key factor being that shared costs were not deductible for the Chinese subsidiaries. Art. 41 now removes the tax obstacle by providing a legal framework which may pave the way for China to attract more advanced intangible property and sophisticated services from overseas.

Art. 42 recognizes the importance of APAs. The State Administration of Taxation has developed an APA programme, and some bilateral APAs have been concluded, involving Japan, South Korea and the United States.

Art. 48 of the EIT Law provides that an additional interest levy will be imposed on the amount of adjustments made to transfer pricing transactions. The levy is in addition to the normal tax arising from the adjustment. This levy could be considered the "real teeth" of China's transfer pricing regime. To date, there is no penalty for any transfer pricing adjustments made by the authorities, except for the tax on the adjustment itself. This reduces the incentive for taxpayers to comply until they face a transfer pricing review or audit. The additional interest levy may include a true interest component based on the time value of money and a penalty component. In particular, a retrospective interest charge may have a significant impact given that the tax authorities can investigate as

70 The most comprehensive set of guidelines is the "Tax Administration Rules and Procedures for Transactions between Associated Enterprises (Trial)", [1998] Guo Shui $\mathrm{Fa}$, No. 59. This circular consists of 52 articles organized in 12 chapters. China's transfer pricing rules generally follow the international concepts and the arm's length principle expounded in the OECD Transfer Pricing Guidelines, although neither the FEIT Law nor the 1998 transfer pricing circular specifically refers to the OECD Guidelines. 
far back as ten years. The EIT Law does not state whether the imposition of the additional interest levy will be retrospective or prospective or the rate of interest and methodology to be applied.

\section{THIN CAPITALIZATION}

The thin capitalization rule is found in Art. 46 of the EIT Law:

Interest accrued to the portion of debt exceeding the specified ratio of debt and equity investment received from an associated enterprise is not deductible in computing taxable income.

According to Art. 46, if the debt/equity ratio exceeds a specified level, the excess interest cannot be deducted in computing taxable income. This is the first thin capitalization rule in China. It applies to loans from related parties only. Key concepts, such as "debt", "equity", "related party" and "back-to-back loans", are expected to be defined in the forthcoming implementation regulations.

\section{CFC RULE}

Taxpayers can defer the Chinese tax on foreign-source income through the use of foreign corporations, typically located in a no-tax or low-tax jurisdiction. For the first time, the tax law provides a rudimentary antideferral rule in Art. 45 of the EIT Law:

Where an enterprise that is established by a Chinese resident enterprise in a jurisdiction pays tax at a rate obviously lower than $25 \%$ and does not distribute its profits for reasons other than business needs, the amount of profit that should have been distributed to the Chinese shareholder is included in the income of the Chinese resident.

Unlike the anti-deferral rules of other countries (such as the US Subpart F rules or the Canadian foreign accrual property income (FAPI) rules), Art. 45 of the EIT Law does not distinguish between foreign portfolio income 
and business income. Instead, it uses the "jurisdiction" approach by applying the CFC rule to the total income of a CFC in a low-tax jurisdiction (i.e. a jurisdiction whose tax rate is lower than the rate under the EIT Law). In addition, Art. 45 has a "business reason/purpose" test -that is, the income that is retained by the CFC and not distributed to the Chinese shareholders for business reasons is not subject to the imputed dividend rule.

The target of imputed dividend taxation in Art. 45 is apparently the use of tax havens by Chinese enterprises to keep funds away from China. It is unclear whether making a portfolio investment outside China meets the "business reason" test. It is also unclear how the State Administration of Taxation plans to obtain information on offshore investments. Because this rule applies only to enterprises, wealthy individuals are not affected by it.

\section{GENERAL ANTI-AVOIDANCE RULE}

Art. 47 of the EIT Law provides:

Where an enterprise enters into an arrangement that has no reasonable commercial purpose, thereby reducing its taxable revenue or income, the tax authority has the power to make adjustments based on reasonable methods.

This rule formally authorizes the Chinese tax authorities to make an adjustment if the taxpayer enters into an arrangement without a "reasonable commercial purpose". This is a strong signal of the tax authorities' growing scrutiny of anti-avoidance schemes. Presumably, this rule applies when a transactions avoids the application of specific antiavoidance rules. Art. 48 further provides:

Where the tax authority has made adjustments in accordance with the above rules in this Chapter, the enterprise must pay the tax arrears as well as a special interest levy imposed under regulations promulgated by the State Council. 


\section{CONCLUSIONS}

The promulgation of the EIT Law is perceived to reflect "a growing confidence in China's global standing, not only for lower cost manufacturing, but as a consumer market with its own draw". ${ }^{71}$ Investors and capital markets in China appear to welcome the new tax law as they expect the large domestic companies -- the major banks, telecoms companies, and oil and gas producers -- that dominate the indexes of Chinese stock will see their after-tax earnings boosted by the tax changes. ${ }^{72}$ Foreign investors looking for a more transparent and neutral tax policy as part of the investment environment welcome the changes. Similarly, established FIEs that have used up their tax holidays or are engaged in activities that are tax-favoured under the new law (such as research and development, infrastructure projects, and environmental industries) stand to benefit under the new law. ${ }^{73}$ More importantly, foreign manufacturers are making products for sale in China, seizing on its fastgrowing consumer market. The biggest concern thus far is the lack of details for implementing the EIT Law. It is problematic that, at the time of writing (September 2007), the State Council has not released the implementation regulations.

71 Leander, Tom, "The big changes in China's tax code reflect a shift in economic priorities. But much about the law remains a mystery", CFO Asia (May 2007), available at www.cfoasia.com/archives/200705-10.htm. The 2007 tax reform has been perceived to represent China's commitment to the WTO, which can only strengthen China's attraction to foreign investment. The tax increase for FIEs "will not crush out the zest of foreign investment" because "what weighs in their decision is China's huge market potential". Thus far, the negative reaction to the new law is based mostly on the lack of detailed rules and regulations to implement it.

72 Baston, Andrew, "China's Expected New Tax Law would Even the Playing Field", The Wall Street Journal, 26 February 2007, at C9.

73 According to Leander, supra note 71, some multinationals have adapted their business plans to the policy changes. GE (General Electric) China has announced that it will invest USD 50 million in its Shanghai-based technology centre for products serving environmental protection, including more efficient airplane engines and wind power generators, seawater desalination technology, and energy-saving bulbs. 